\title{
Effect of dopant concentration and crystalline structure on the absorption edge in $\mathrm{ZnO}: \mathrm{Y}$ films
}

\author{
${ }^{1}$ Turko B., ${ }^{1}$ Mostovoy U., ${ }^{1}$ Kovalenko M., ${ }^{1}$ Eliyashevskyi Y., ${ }^{1}$ Kulyk Y., \\ ${ }^{1}$ Bovgyra O., ${ }^{1}$ Dzikovskyi V., ${ }^{2}$ Kostruba A., ${ }^{3}$ Vlokh R., ${ }^{2}$ Savaryn V., \\ ${ }^{2}$ Stybel V., ${ }^{2}$ Tsizh B. and ${ }^{4}$ Majevska S. \\ ${ }^{1}$ Ivan Franko National University of Lviv, 50 Dragomanov Street, 79005 Lviv, \\ Ukraine \\ ${ }^{2}$ Stepan Gzhytskyi National University of Veterinary Medicine and \\ Biotechnologies, 50 Pekarska Street, 79010 Lviv, Ukraine \\ ${ }^{3}$ O. G. Vlokh Institute of Physical Optics, 23 Drahomanov Street, 79005 Lviv, \\ Ukraine \\ ${ }^{4}$ Lviv State University of Physical Culture, 11 Kostiushka Street, 79000 Lviv, \\ Ukraine
}

Received: 08.12 .2020

\begin{abstract}
We study the crystalline structure and absorption spectra for the zinc oxide films with different levels of yttrium doping. The films are deposited on glass substrates, using radio-frequency magnetron sputtering. We estimate the concentration of free charge carriers and show that the 'blue' shift of the fundamental absorption edge in $\mathrm{ZnO}: \mathrm{Y}$ films with increasing doping level (up to 4.7 wt. \%) is explained by Burstein-Moss effect. At higher concentrations of yttrium, behaviour of the fundamental absorption edge is described by a known empirical Urbach rule.
\end{abstract}

Keywords: yttrium-doped zinc oxide, absorption edge, optical bandgap, crystalline structure, Burstein-Moss effect.

UDC: $535.3 ; 539.26$

\section{Introduction}

Semiconductor materials based on $\mathrm{ZnO}$ are now considered as the best alternative to indium tin oxide, since they are much cheaper and non-toxic. $\mathrm{ZnO}: \mathrm{Al}$ films have the transmittance coefficient of approximately $90 \%$ in the visible region and are hardly inferior to the indium tin oxide films as for their resistivity $\left(\sim 10^{-4} \mathrm{Ohm} \times \mathrm{cm}\right)$. There are many companies in the world involved into production of transparent and electrically conductive ZnO-based oxides for the needs of electronics. In particular, «TEL Solar AG» (TOKYO ELECTRON GROUP) employs a completely automated system 'Low Pressure Chemical Vapor Deposition' and produces large-area (1.43 or even $1.54 \mathrm{~m}^{2}$ ) contacts for solar modules, basing on transparent conductive $\mathrm{ZnO}$-based oxides [1]. Transparent conductive $\mathrm{ZnO}$-based oxides are mainly obtained by doping with groupIII elements such as In, Al, and Ga [2]. In spite of great potential practical and fundamental interest, the number of publications that deal with the properties of yttrium-doped zinc oxide films still remains insufficient [3-7]. For optimal application of $\mathrm{ZnO}: \mathrm{Y}$ films, it is necessary to have indepth knowledge of their structure and optical and electrical properties. We note in this relation that we could not find any literature data on the optical properties of yttrium-doped $\mathrm{ZnO}$ films obtained with a standard radio-frequency $(\mathrm{RF})$ magnetron sputtering technique.

The RF magnetron sputtering is among the best techniques applied when manufacturing thin oxide films. Its advantages include suitability for sputtering of highly melting materials, versatility 
and low cost. The efficiency of the RF magnetron sputtering is owing to high activity of gascomponent molecules, which is stimulated by the action of RF plasma [8].

In this report, we present the results for the influence of surface morphology on the optical spectra and the electrical properties of thin zinc oxide films which are characterized by different levels of yttrium doping. Our films are deposited on glass substrates using the RF magnetron sputtering method.

\section{Experimental}

The films of $\mathrm{ZnO}: \mathrm{Y}$ (with $0,2.4,3.2,4.7,5.5$ and 6.6 wt. \% of $\mathrm{Y}$ ) were obtained by the RF magnetron sputtering on glass substrates in argon atmosphere. The working gas pressure was equal to $0.1 \mathrm{~Pa}$. The other important parameters were as follows: the high-frequency oscillator power $75 \mathrm{~W}$, the distance between the target and the substrate $60 \mathrm{~mm}$, the magnetic-field induction $0.1 \mathrm{~T}$, and the substrate temperature $300^{\circ} \mathrm{C}$. The target was prepared from a compressed mixture of $\mathrm{ZnO}$ (chemically pure grade) and $\mathrm{Y}_{2} \mathrm{O}_{3}$ (pure grade) powders used in appropriate proportions. The sputtering time was 1 hour. According to ellipsometric data, the thickness of the films was about $0.6 \mu \mathrm{m}$.

The surface morphology of our samples was studied using a Solver P47-PRO atomic force microscope. The X-ray diffraction measurements were carried out using a STOE STADI P diffractometer with linear position-sensitive detector in a transmission Bragg-Brentano geometry $\left(\mathrm{Cu} K_{\alpha 1}\right.$ radiation at $\lambda=0.15406 \mathrm{~nm}, \mathrm{Ge}(111)$ monochromator, detector scanning step $0.480^{\circ} 2 \theta$, accumulation time $320 \mathrm{~s}, 2 \theta$-angle resolution $0.015^{\circ}$, and $2 \theta$-range $23-115 \mathrm{deg}$ ).

ex situ ellipsometry measurements were performed with a serial null-ellipsometer LEF-3 M in a standard PCSA (polarizer-compensator-sample-analyzer) arrangement. He-Ne laser $(\lambda=$ $632.8 \mathrm{~nm}$ ) was a light source. Finally, we used a ZMR-3 mirror monochromator to study absorption of light in the UV and visible spectral ranges.

\section{Results and discussion}

$\mathrm{X}$-ray diffraction pattern for the $\mathrm{ZnO}: \mathrm{Y}$ thin films (with $0,2.4,3.2$ and $4.7 \mathrm{wt} . \%$ of $\mathrm{Y}$ ) are shown in Fig. 1 . The results indicate a polycrystalline nature of the films which manifest a hexagonal wurtzite structure (JCPDS-036-1451) [6]. A prominent peak corresponding to (002) plane has been observed for all of our samples. No additional peaks due to segregated yttrium-rich phases have been found in any of the films under test, thus indicating their high phase homogeneity [7]. This also indicates that $\mathrm{Y}$ ions are uniformly substituted into either $\mathrm{Zn}$ sites or interstitial sites in the $\mathrm{ZnO}$ lattice. A decrease in the intensity of (002) reflection is noticed with increasing doping concentration. This fact suggests a gradual loss of crystallinity (see Refs. [4, 6, 7]). $\mathrm{Zn}^{2+}$ and $\mathrm{Y}^{3+}$ ions have the radii equal respectively to 0.088 and $0.104 \mathrm{~nm}$, and different oxidation states [6]. The substitution of an atom with another one of larger size would result in increased interplanar spacing. However, if the oxidation state of the substituting atom is higher, then we would have the opposite effect [6].

The average crystallite sizes $D$ of undoped and Y-doped $\mathrm{ZnO}$ films have been calculated using the full width at the half maximum of the (002) diffraction peak and the angle of diffraction $\theta$ in the Debye-Scherer's formula [8]:

$$
D=\frac{0.9 \lambda}{\beta \cos \theta},
$$

where $\lambda$ is the $\mathrm{X}$-ray wavelength, $\beta$ the full width at the half maximum, and $\theta$ the Bragg angle of the diffraction peak. 


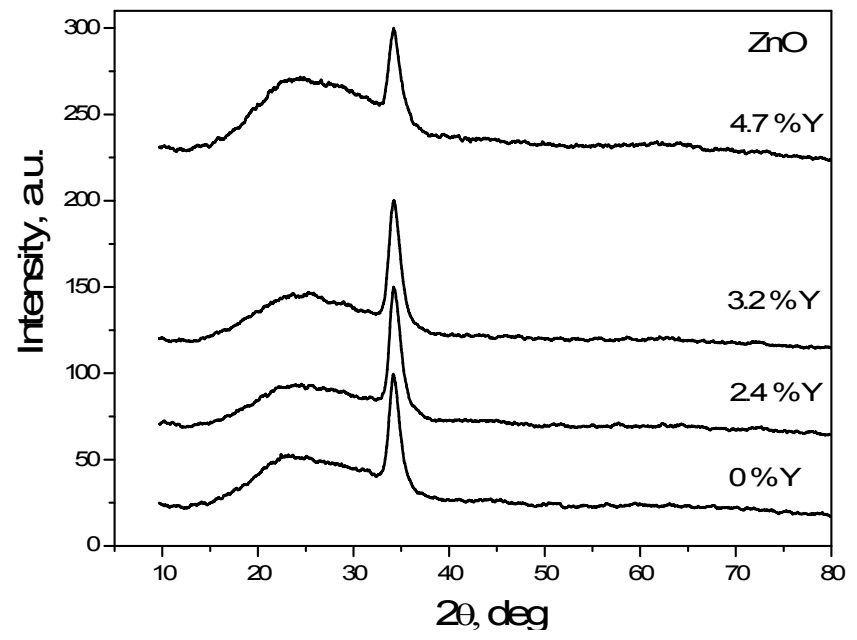

Fig. 1. X-ray diffraction patterns obtained for as-grown $\mathrm{ZnO}: \mathrm{Y}$ films with $0,2.4,3.2$ and $4.7 \mathrm{wt}$ \% of yttrium.

The dislocation density $\delta$ and the micro-strain $\varepsilon$ in the deposited films have been calculated as [7]

$$
\begin{aligned}
& \delta=1 / D^{2}, \\
& \varepsilon=\beta /(4 \tan \theta) .
\end{aligned}
$$

Table 1 presents some structural parameters of our $\mathrm{ZnO}: \mathrm{Y}$ samples calculated from the $\mathrm{X}$-ray diffraction data.

Table 1. Some structural parameters of our $\mathrm{ZnO}: \mathrm{Y}$ samples calculated from the $\mathrm{X}$-ray diffraction data.

\begin{tabular}{ccccc}
\hline $\begin{array}{c}\text { Yttrium dopant } \\
\text { concentration, wt. \% }\end{array}$ & $\begin{array}{c}\text { Full width at the half } \\
\text { maximum, deg }\end{array}$ & $\begin{array}{c}\text { Crystallite } \\
\text { size, } \mathrm{nm}\end{array}$ & $\begin{array}{c}\text { Dislocation } \\
\text { density, } 10^{-16}\end{array}$ & $\begin{array}{c}\text { Micro-strain, } \\
10^{-3}\end{array}$ \\
\hline 0 & 1.17 & 5.0 & 4.0 & 4.9 \\
2.4 & 1.30 & 10.0 & 1.0 & 5.4 \\
3.2 & 1.33 & 9.6 & 1.1 & 5.5 \\
4.7 & 1.37 & 9.2 & 1.2 & 5.7 \\
\hline
\end{tabular}

As mentioned above, the surface morphology of undoped and yttrium-doped $\mathrm{ZnO}$ films has been monitored with the atomic force microscope. The dependences of crystallinity level and crystallite sizes on the yttrium concentration have been revealed from their micrographs (see Fig. 2). The root mean square roughness and the average grain size have been measured on the area $5 \times 5 \mu \mathrm{m}^{2}$. Table 2 presents these parameters as functions of the doping level.

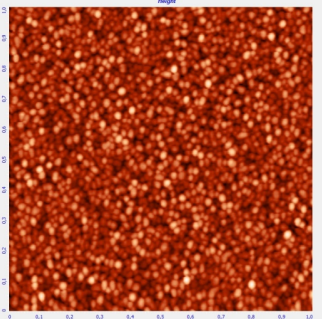

(a)

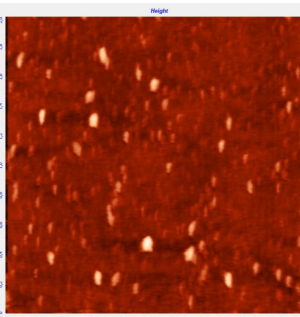

(b)

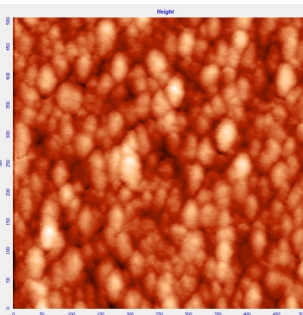

(c)

Fig. 2. Three-dimensional atomic force microscope micrographs obtained for $\mathrm{ZnO}: \mathrm{Y}$ films with different yttrium concentrations: (a) 2.4, (b) 3.2 and (c) 4.7 wt. \%. 
Table 2. Root mean square roughnesses and average grain sizes for $\mathrm{ZnO}: \mathrm{Y}$ films as functions of yttrium concentration.

\begin{tabular}{ccc}
\hline $\begin{array}{c}\text { Yttrium dopant concentration, } \\
\text { wt. \% }\end{array}$ & $\begin{array}{c}\text { Root mean square } \\
\text { roughness, nm }\end{array}$ & Average grain size, nm \\
\hline 2.4 & 1.7 & 5.1 \\
3.2 & 0.6 & 3.5 \\
4.7 & 1.2 & 5.9 \\
\hline
\end{tabular}

A tendency to reduced average size of crystallites with increased yttrium concentration is observed with both the atomic force microscopic and X-ray diffraction data. According to the literature, enrichment of surface with $\mathrm{Y}^{3+}$ hinders a growth of crystallites $[4,6,9]$.

The absorption coefficient $\alpha$ has been calculated using the Bouguer-Lambert-Beer formula and the transmission spectra. In general case, the absorption coefficient is linked to the bandgap $E_{g}$ by the relation [2]

$$
\alpha h v=B\left(h v-E_{g}\right)^{r},
$$

where the $r$ coefficient is equal to $1 / 2$ for direct allowed transitions and $B$ is a constant that remains practically independent of the photon energy. The optical bandgaps have been obtained from the dependences $(\alpha h v)^{2}$ vs. $h v$ in the region of large absorption, while extrapolating linear parts of the curves towards the level $(\alpha h v)^{2}=0$ [2]. The analysis of fundamental absorption edge with Eq. (4) shows that the optical bandgap for the undoped $\mathrm{ZnO}$ amounts to $E_{g}=3.22 \mathrm{eV}$ (see Fig. 3).

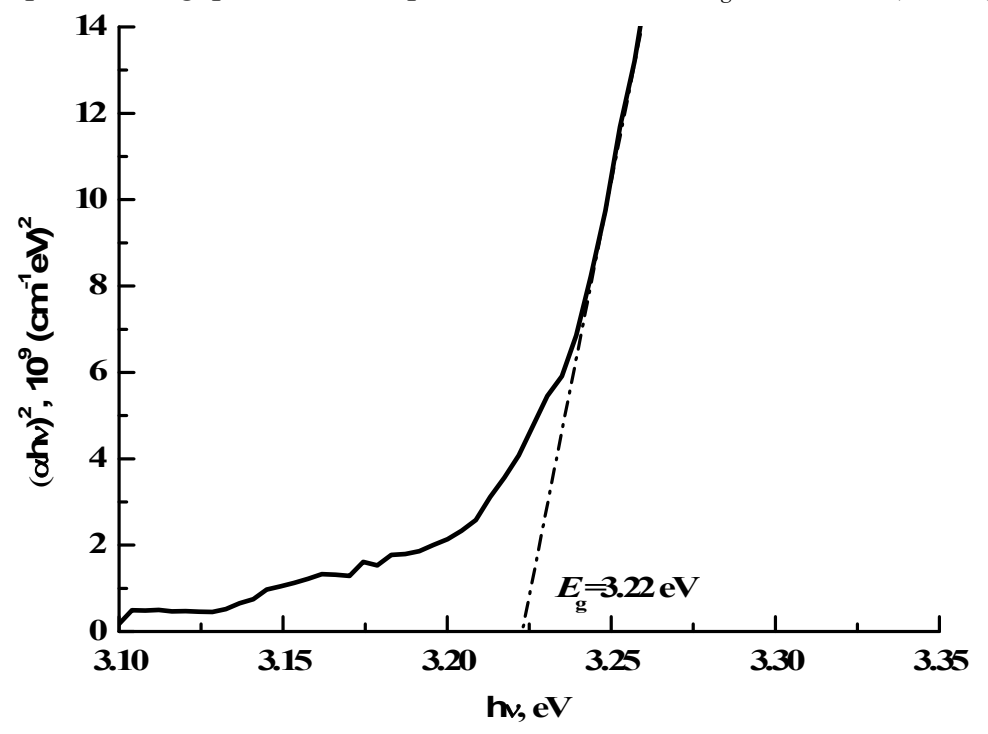

Fig. 3 Absorption spectrum measured for a $0.6 \mu \mathrm{m}$-thick undoped $\mathrm{ZnO}$ film and represented in the coordinates $(a h v)^{2}$ vs. $h v$. The substrate temperature is equal to $300^{\circ} \mathrm{C}$.

Fig. 4 shows the intrinsic absorption spectra for $\mathrm{ZnO}: \mathrm{Y}$ films in the coordinates $(\alpha h v)^{2}=f(h v)$. Using Eq. (4) and the data of Fig. 4, we obtain the optical bandgaps $E_{g} \approx 3.23 \mathrm{eV}, 3.24 \mathrm{eV}, 3.25$ $\mathrm{eV}, 3.25 \mathrm{eV}$ and $3.24 \mathrm{eV}$ respectively for the dopant concentrations 2.4, 3.2, 4.7, 5.5 and 6.6 wt. \%. According to the conclusions [7], the increase in the optical bandgap observed for our films due to doping with yttrium (up to 4.7 wt. \%) can be explained by a so-called Burstein-Moss effect. A shift towards lower photon energies detected for the higher doping levels can be attributed to 'apparition' of energy states in the forbidden band close to the band edges. This phenomenon is described by Urbach's empirical law [7]. 


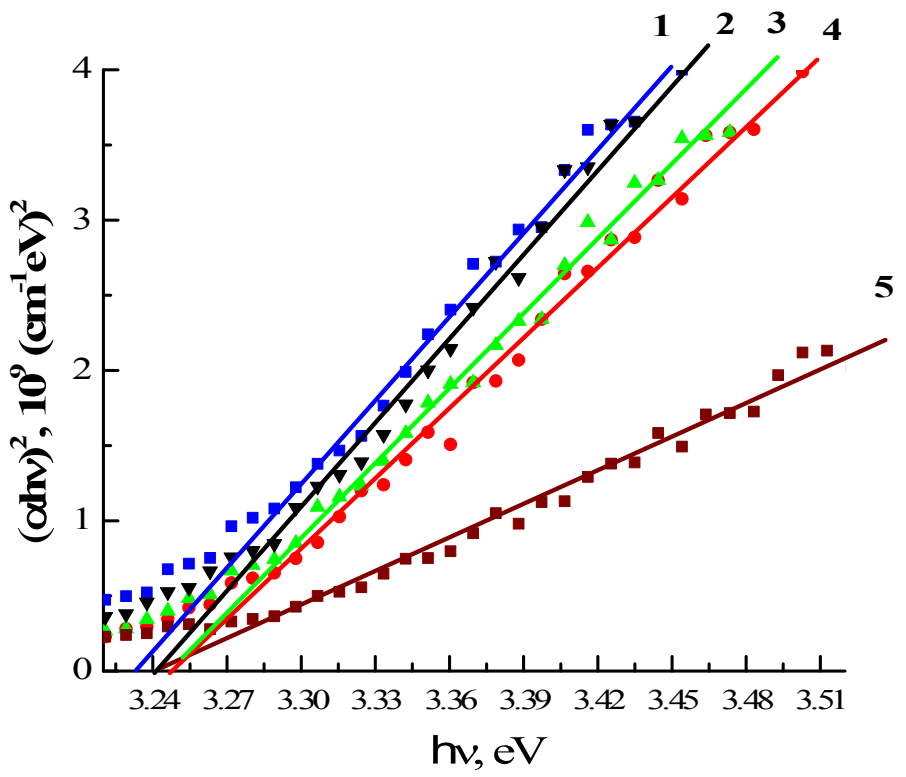

Fig. 4. Absorption spectra for $\mathrm{ZnO}: \mathrm{Y}$ films plotted in the coordinates $(\alpha h v)^{2}$ vs. $h v$. Dopant concentrations $C_{\mathrm{Y}}$ are equal to 2.4 (1), 3.2 (2), 4.7 (3), 5.5 (4) and 6.6 wt. \% (5).

According to the Burstein-Moss effect, increase in the bandgap in an $n$-type semiconductor with a parabolic dispersion law for energy bands, which arises due to doping, can be described by its increment $\Delta E_{g}$ as [2]

$$
\Delta E_{g}=h^{2}\left(3 \pi^{2} n\right)^{3 / 2} /\left(8 \pi^{2} m^{*}\right),
$$

where $m^{*}$ is the effective mass of electron in the conduction band, $h$ the Planck's constant and $n$ the carrier concentration. According to Eq. (5), the bandgap increases as the carrier concentration does. Basing on Eq. (5), one can estimate the concentration of free charge carriers in the $\mathrm{ZnO}: \mathrm{Y}$ films, using two alternative values known for the effective electron mass in $\mathrm{ZnO}\left(m^{*}=0.24 m_{e}\right.$ and $\left.m^{*}=0.35 m_{e}[2]\right)$. The results of the calculations are gathered in Table 3 .

Table 3. Concentrations of free electrons in $\mathrm{ZnO}: \mathrm{Y}$ films, as calculated from the Burstein-Moss model.

\begin{tabular}{cccc}
\hline Sample & $\Delta E_{g}, \mathrm{eV}$ & $\begin{array}{c}n, 10^{18} \mathrm{~cm}^{-3} \\
\left(m^{*}=0.24 m_{\mathrm{e}}\right)\end{array}$ & $\begin{array}{c}n, 10^{18} \mathrm{~cm}^{-3} \\
\left(m^{*}=0.35 m_{\mathrm{e}}\right)\end{array}$ \\
\hline ZnO:Y (2.4 wt. \%) & 0.01 & 0.6 & 1.0 \\
ZnO:Y (3.2 wt. \%) & 0.02 & 1.6 & 2.8 \\
ZnO:Y (4.7 wt. \%) & 0.03 & 2.9 & 5.1 \\
\hline
\end{tabular}

Our results correlate satisfactorily with the data reported in Refs. $[4,6,7]$. So, the authors [4] have found a tendency to increasing optical bandgap with increasing yttrium concentration in the $\mathrm{Zn}_{1-\mathrm{x}} \mathrm{Y}_{\mathrm{x}} \mathrm{O}(0 \leq \mathrm{x} \leq 0.05)$ nanopowders prepared with the sol-gel method. The authors of Ref. [6] have observed an increase in the optical bandgap in the $\mathrm{ZnO}: \mathrm{Y}$ films formed using a pulsed-laser deposition. Here the impurity concentrations are up to $2 \mathrm{wt} \%$, i.e. the Burstein-Moss effect should work. On the other hand, it has been detected that the bandgap decreases at higher impurity concentrations. 


\section{Conclusions}

In summary, we have obtained the films of $\mathrm{ZnO}$ and $\mathrm{ZnO}: \mathrm{Y}$ (with 2.4, 3.2, 4.7, 5.5 and 6.6 wt. \% of yttrium), using the RF magnetron sputtering on the glass substrates. According to the ellipsometric data, the thickness of the films is about $0.6 \mu \mathrm{m}$. The crystalline structure and the optical absorption spectra of these films are investigated. For all the experimental samples, the peak (002) is the only available in the X-ray diffraction spectra. For any experimental film samples, no diffraction peaks are found, which would have been associated with the presence of metallic yttrium or its oxides.

The average crystallite sizes, the dislocation density and the micro-strains in the films have been calculated from the X-ray diffraction data. We observe a blue shift of the absorption edge in the $\mathrm{ZnO}: \mathrm{Y}$ films whenever the yttrium impurity concentration increases up to $4.7 \mathrm{wt} . \%$, and a red shift for higher concentrations. Basing on the optical absorption spectra for the $\mathrm{ZnO}: \mathrm{Y}$ films, we obtain the approximate optical bandgaps $E_{g} \approx 3.22 \mathrm{eV}, 3.23 \mathrm{eV}, 3.24 \mathrm{eV}, 3.25 \mathrm{eV}, 3.25 \mathrm{eV}$ and $3.24 \mathrm{eV}$ respectively for the concentrations $0,2.4,3.2,4.7,5.5$ and $6.6 \mathrm{wt}$. \%.

The concentration of free charge carriers in the $\mathrm{ZnO}: \mathrm{Y}$ films turns out to be of the order of $10^{18} \mathrm{~cm}^{-3}$. We demonstrate that the blue shift of the fundamental absorption edge in the $\mathrm{ZnO}: \mathrm{Y}$ films, which occurs with increasing impurity concentration, is due to the Burstein-Moss effect. On the contrary, the red shift for the higher concentrations is due to 'apparition' of energy states in the forbidden band close to the band edges.

\section{References}

1. Turko B and Kapustianyk V. ZnO as multifunctional material for nanoelectronics ( $2^{\text {nd }}$ Suppl. Ed.). Beau Bassin: Scholars' Press (2020).

2. Kapustianyk V B, Turko B I, Rudyk V P, Kulyk B Y and Rudko M S, 2015. Effect of dopants and surface morphology on the absorption edge of $\mathrm{ZnO}$ films doped with In, $\mathrm{Al}$, and Ga. J. Appl. Spectrosc. 82: 153-156.

3. Ivanova T, Harizanova A, Koutzarova $\mathrm{T}$ and Vertruyen B, 2016. Investigation of sol-gel yttrium doped $\mathrm{ZnO}$ thin films: structural and optical properties. J. Phys.: Conf. Ser. 682: 012023.

4. Anandan S and Muthukumaran S, 2013. Influence of yttrium on optical, structural and photoluminescence properties of $\mathrm{ZnO}$ nanopowders by sol-gel method. Opt. Mater. 35: 22412249.

5. Bouaine A, Guendouz H, Schmerber G and Zehouma Y, 2019. Synthesis and characterization of $\mathrm{Y}$-doped $\mathrm{ZnO}$ thin films prepared by spin-coating technique. Austr. J. Bas, Appl. Sci. 13: 49-54.

6. Youvanidha A, Vidhya B, Issac Nelson P, Rathes Kannan R and Suresh Babu S K, 2019. Investigation on the structural, optical and electrical properties of $\mathrm{ZnO}-\mathrm{Y}_{2} \mathrm{O}_{3}(\mathrm{YZO})$ thin films prepared by PLD for TCO layer applications. AIP Conf. Proc. 2166: 020023-1-020023-8.

7. Bazta O, Urbieta A, Piqueras J, Fernández P, Addou M, Calvino J J and Hungría A B, 2019. Influence of yttrium doping on the structural, morphological and optical properties of nanostructured $\mathrm{ZnO}$ thin films grown by spray pyrolysis. Ceramics International. 45: $6842-6852$.

8. Panasyuk M R, Turko B I, Kapustianyk V B, Lubochkova G A, Rudyk V P, Vas'kiv A P and Davydov V M, 2005. Manufacturing technology, optical and spectral properties of nanostructurized thin $\mathrm{ZnO}$ films. Functional Mater. 12: 746-749. 
9. Atribak I, Bueno-López A and García-García A, 2009. Role of yttrium loading in the physicochemical properties and soot combustion activity of ceria and ceria-zirconia catalysts. J. Mol. Catal. A: Chem. 300: 103-110.

Turko B., Mostovoy U., Kovalenko M., Eliyashevskyi Y., Kulyk Y., Bovgyra O., Dzikovskyi V., Kostruba A., Vlokh R., Savaryn V., Stybel V., Tsizh B. and Majevska S. 2021 Effect of dopant concentration and crystalline structure on the absorption edge in $\mathrm{ZnO}: \mathrm{Y}$ films. Ukr.J.Phys.Opt. 22: 31 - 37. doi: 10.3116/16091833/22/1/31/2021

Анотація. Вивчено кристалічну структуру та спектри поглинання плівок оксиду циинку 3 різними рівнями легування ітрісм. Плівки наносили на скляні підкладки за допомогою радіочастотного магнетронного розпилення. Оцінено концентрацію вільних носіїв заряду $i$ показано, щзо «синій» зсув краю фундаментального поглинання у плівках ZnO:Y, який спостерігаємо зі зростанням рівня легування до 4,7мас. \%, пояснюється ефектом Бурштейна-Мосса. За вищих концентрацій ітрію поведінка краю фундаментального поглинання описується відомим емпіричним правилом Урбаха. 